\title{
Pengembangan MedPAK: Media Pembelajaran Pendidikan Antikorupsi Berbasis Multimedia
}

\author{
Yani Prihati, Sinta Tridian Galih, Tri Karyanti \\ Program Studi Teknik Informatika \\ Universitas AKI \\ Semarang \\ yani.prihati@unaki.ac.id
}

\begin{abstract}
Abstrak-Data menunjukkan bahwa dari tahun ke tahun Indeks Persepsi Korupsi Indonesia terus meningkat. Hal ini menunjukkan bahwa komitmen pemerintah yang direalisasikan melalui berbagai upaya dalam menangani masalah korupsi telah berada di jalur yang tepat walaupun belum optimal. Korupsi masih menjadi masalah yang serius di Indonesia karena masih dapat dilakukan oleh siapa saja, terjadi di berbagai tempat, dan dalam berbagai jenis perkara dengan jumlah yang cenderung meningkat dari tahun ke tahun. Undang-undang Nomor 30 Tahun 2002 Pasal 13 menyebutkan bahwa salah satu upaya pencegahan yang dapat dilaksanakan oleh KPK adalah menyelenggarakan program pendidikan antikorupsi pada setiap jenjang pendidikan. Hal ini menunjukkan bahwa dunia pendidikan penting dilibatkan dalam upaya pemberantasan korupsi. Penelitian ini bertujuan untuk mengembangkan media pembelajaran Pendidikan Antikorupsi berbasis multimedia untuk tingkat perguruan tinggi yang disebut MedPAK. MedPAK dikembangkan dengan mengadopsi metode Research and Development. Hasil penilaian materi pada MedPAK menunjukkan rata-rata persentase $88 \%$ sedangkan hasil penilaian media adalah sebesar $84 \%$ di mana keduanya termasuk kategori baik. Dapat disimpulkan bahwa MedPAK layak untuk digunakan.
\end{abstract}

Kata kunci: media pembelajaran antikorupsi; MedPAK; multimedia

\section{Pendahuluan}

Setiap tahun sejak 1995 Transparency International, sebuah organisasi internasional yang bertujuan memerangi korupsi, menerbitkan Indeks Persepsi Korupsi (IPK). IPK menunjukkan urutan negara di dunia yang dinilai berdasarkan persepsi (anggapan) publik terhadap korupsi di jabatan publik dan politis. Pada saat pertama kali IPK diterbitkan di tahun 1995 Indonesia berada di urutan terbawah dari 41 negara dengan skor 1,9. Lima tahun kemudian pada tahun 2000 Indonesia berada di urutan ke 85 dari 90 negara dengan skor 1,7 [1]. Data menunjukkan bahwa dari tahun ke tahun Indeks Persepsi Korupsi Indonesia terus mengalami peningkatan yang berarti bahwa upaya pemberantasan korupsi yang dilakukan di Indonesia memperoleh apresiasi baik dari publik nasional maupun internasional. Dapat disimpulkan bahwa upaya yang dilakukan oleh pemerintah dalam menangani masalah korupsi telah berada di jalur yang tepat walaupun belum optimal.

Berdasarkan data yang dilansir di situs resmi KPK [2] selama kurun waktu tahun 2004-2017 rata-rata persentase pertambahan banyaknya kasus tindak korupsi yang diselidiki oleh KPK adalah 15,6\% per tahun dan rata-rata persentase pertambahan banyak kasus yang dieksekusi adalah 34,6\%. Dilihat dari jenis perkara, dalam kurun waktu yang sama, jenis perkara dengan persentase tertinggi adalah penyuapan $(57,6 \%)$, pengadaan barang/jasa $(24,9 \%)$ sampai yang terendah adalah merintangi proses KPK (1\%). Angka-angka tersebut menunjukkan bahwa korupsi masih menjadi masalah yang serius di Indonesia. Korupsi masih dapat dilakukan oleh siapa saja, terjadi di berbagai tempat, dan dalam berbagai jenis perkara dengan jumlah yang cenderung meningkat dari tahun ke tahun.

Melalui Undang-undang Nomor 30 Tahun 2002, pemerintah membentuk Komisi Pemberantasan Korupsi (KPK). Dalam undang-undang tersebut disebutkan bahwa KPK merupakan sebuah lembaga negara yang bersifat independen, yang dalam melaksanakan tugas dan wewenangnya bebas dari kekuasaan manapun dan menyerahkan amanat kepada lembaga ini untuk melakukan pemberantasan korupsi secara profesional, intensif dan berkesinambungan dengan tujuan untuk meningkatkan daya guna dan hasil guna terhadap upaya pemberantasan tindak pidana korupsi [3]. Secara umum, KPK memiliki dua tugas utama yaitu menindak dan mencegah korupsi.

Undang-undang Nomor 30 Tahun 2002 Pasal 13 menyebutkan bahwa salah satu upaya pencegahan yang dapat dilaksanakan oleh KPK adalah bekerjasama dengan dunia pendidikan pada setiap jenjang untuk menyelenggarakan program pendidikan antikorupsi. Hal ini menunjukkan bahwa dunia pendidikan penting dilibatkan dalam upaya pemberantasan korupsi [3].

Hal ini senada dengan pendapat Yusrianto Kadir yang menyatakan bahwa dengan pendidikan, berkembangnya mental korupsi pada generasi muda Indonesia dapat dicegah sehingga budaya korupsi di masyarakat juga dapat dicegah [4]. Alasan lain pentingnya melibatkan dunia pendidikan dalam pencegahan korupsi dikemukakan oleh Hasan yang berpendapat bahwa pola pikir, sikap, dan perilaku antikorupsi harus ditanamkan dan dibudayakan melalui sekolah karena pada dasarnya sekolah adalah proses pembudayaan [5]. 
Suryani menyatakan bahwa di tingkat pendidikan tinggi, pendidikan antikorupsi diharapkan dapat menanamkan nilai-nilai antikorupsi sehingga secara sadar mahasiswa memiliki pemahaman tentang tindak korupsi dan pemberantasannya. Dengan pemahaman ini, mahasiswa diharapkan dapat berperan aktif dalam dalam upaya pencegahan korupsi terutama dengan ikut membangun budaya antikorupsi di masyarakat [6]

Dari penjelasan-penjelasan di atas dapat disimpulkan bahwa sampai saat ini, korupsi masih menjadi masalah serius di Indonesia dan salah satu upaya pencegahan yang dapat dilakukan adalah dengan melibatkan dunia pendidikan.

Tujuan dari penelitian ini adalah untuk mengembangkan sebuah media pembelajaran pendidikan antikorupsi berbasis multimedia bagi perguruan tinggi yang diberi sebutan MedPAK. Hosfstetter (dalam Bimantoro) menjelaskan tiga keunggulan multimedia yaitu dalam hal format file yang bisa diakses (teks, grafik, audio, video, dan animasi), kemudahan akses melalui link maupun tool yang tepat, dan kemudahan pemakai dalam melakukan navigasi, interaksi, kreasi, dan berkomunikasi [7]. Hal ini senada dengan Binanto (dalam Pariyatin) yang menjelaskan bahwa multimedia dapat digunakan dalam banyak bidang termasuk bidang pendidikan karena kekayaan elemen, kemudahan penggunaan, dan variasi konten. Dengan kelebihan-kelebihan tersebut, multimedia dapat dimanfaatkan untuk mengembangkan media pembelajaran menjadi lebih menarik dan lebih lengkap [8].

Multimedia dapat dimanfaatkan dalam berbagai fungsi tetapi pada fungsi yang berbeda bisa jadi multimedia dimanfaatkan dengan cara yang berbeda. Sebagai contoh, multimedia sebagai media pembelajaran berbeda dari multimedia sebagai media presentasi. Hooper (dalam Gde) menyebutkan bahwa pemanfaatan multimedia sebagai media presentasi tidak menuntut pengguna berinteraksi secara aktivitas di dalamnya tetapi pemanfaatan multimedia sebagai media pembelajaran harus melibatkan pengguna dalam akitivitas-aktivitas yang menuntut proses mental di dalam pembelajaran [9].

Ariani (dalam Efendi, Sumarni, Efendi) mengemukakan beberapa manfaat multimedia pembelajaran baik bagi pengajar, peserta belajar maupun proses pembelajaran. Manfaat utama bagi pengajar adalah berkurangnya jumlah waktu mengajar atau pun ceramah. Bagi proses pembelajaran, multimedia dapat menghidupkan teks dengan menyertakan bunyi, gambar, musik, animasi, dan video sehingga proses pembelajaran akan menjadi lebih menarik dan interaktif. Bagi peserta belajar, multimedia dapat meningkatkan motivasi, sikap, dan perhatian belajar [10].

Karena menggunakan beberapa media secara bersamaan, diharapkan media pembelajaran ini dapat menarik dan meningkatkan kemauan belajar mahasiswa sehingga dapat meningkatkan capaian pembelajaran.

\section{Metode}

Tujuan penelitian ini adalah mengembangkan MedPAK yang merupakan media pembelajaran yang dilengkapi dengan rencana pembelajaran berupa silabus dan rencana pembelajaran semester. Untuk mencapai tujuan tersebut maka penelitian dilaksanakan dengan mengadopsi metode penelitian dan pengembangan (Research and Development - R $\mho D$ ) yang mengacu pada model pengembangan Plomp. Hobri (dalam Magfirah dkk) menyebutkan bahwa model Plomp ini terdiri dari lima tahap yang berfokus kepada pengembangan produk pembelajaran yaitu analisis, perancangan, pengembangan, pengujian dan revisi, dan implementasi [11]. Model ini diimplementasikan melalui aktivitas-aktivitas yang disajikan dalam Gambar 1.

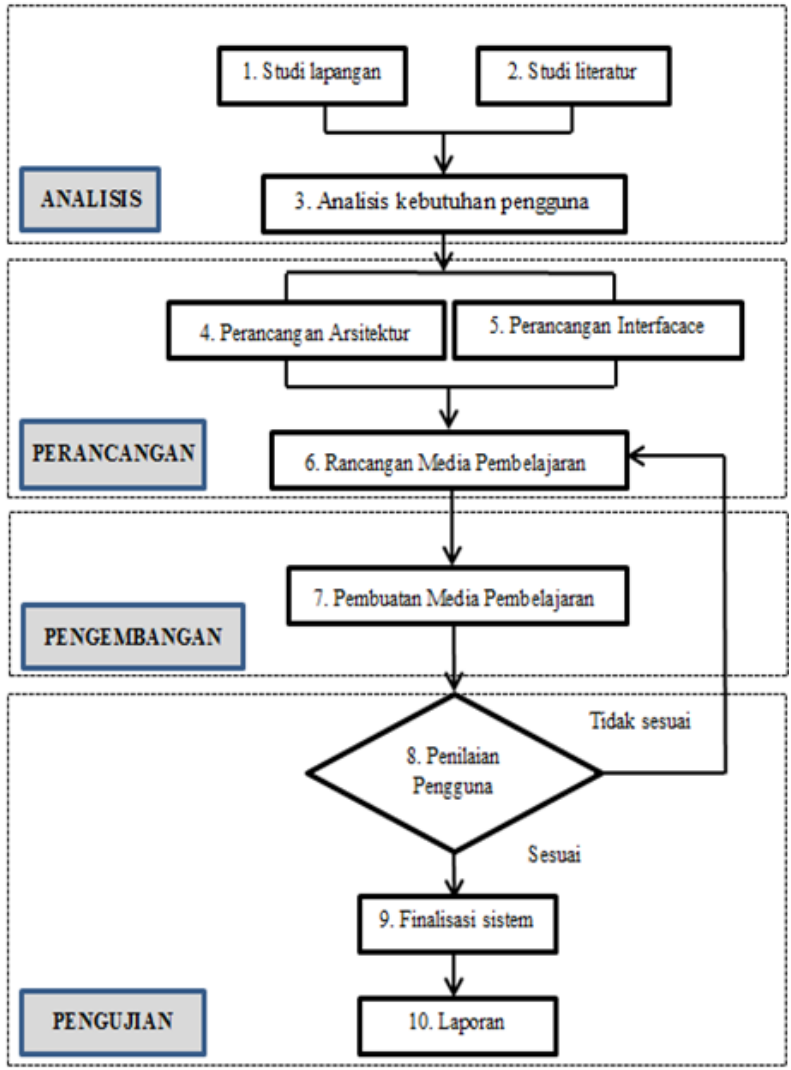

Gambar 1. Aktivitas penelitian

Pada tahap pengujian, dilakukan penilaian oleh ahli materi dan ahli media untuk menilai kesiapan pemanfaatan MedPAK.

Pengumpulan data dilakukan dengan menggunakan kuisioner untuk merekam penilaian para ahli terhadap media yang telah dikembangkan

\section{Hasil}

Studi lapangan dilakukan untuk mengumpulkan data-data berkaitan dengan pembelajaran pendidikan antikorupsi meliputi silabus dan rencana pembelajaran semester serta proses pembelajaran. Diperoleh hasil bahwa satu perguruan tinggi menyajikan materi pendidikan antikorupsi pada mata kuliah tersendiri terjadwal dalam 16 minggu perkuliahan termasuk tes sedangkan sisanya menyajikan materi pendidikan antikorupsi dengan menyisipkannya pada mata kuliah yang sesuai terjadwal dalam 2-4 minggu perkuliahan. Fakta lain yang diperoleh adalah bahwa di sebagian besar perguruan tinggi, materi pendidikan antikorupsi masih disajikan secara searah dengan metode ceramah dan contoh-contoh serta kasus-kasus yang disajikan kurang sesuai dengan dunia 
nyata yang dihadapi oleh mahasiswa. Sebagai contoh, kasus-kasus perilaku korupsi yang disajikan dilakukan oleh pegawai negeri atau pejabat negara sehingga dapat menimbulkan kesan pada mahasiswa bahwa perilaku korupsi tidak mungkin terjadi pada mereka karena mereka bukan pegawai negeri atau pejabat negara.

Studi literatur dilakukan dengan mempelajari referensi-referensi yang relevan dengan materi pendidikan antikorupsi termasuk dokumen-dokumen yang diterbitkan oleh Kementerian Pendidikan dan Kebudayaan. Dari proses ini diperoleh hasil bahwa materi pendidikan antikorupsi di tingkat perguruan tinggi terdiri dari delapan materi, yaitu pengertian korupsi, faktor penyebab korupsi, dampak masif korupsi, nilai dan prinsip antikorupsi, upaya pemberantasan korupsi, gerakan, kerja sama, instrumen internasional pencegahan korupsi, tindak pidana korupsi dalam peraturan perundang-undangan di Indonesia, serta peranan mahasiswa dalam pencegahan korupsi.

Dari buku Pendidikan Antikorupsi diperoleh informasi bahwa untuk peserta didik tingkat sarjana (S1) terdapat tiga standar kompetensi yang akan dicapai yaitu mahasiswa mampu mencegah dirinya sendiri melakukan tindak korupsi (individual competence), mahasiswa mampu memberikan peringatan kepada orang lain dan mencegah orang lain melakukan tindak korupsi, dan mahasiswa mampu mendeteksi adanya tindak korupsi dan melaporkannya kepada penegak hukum [12]. Junaedi dkk menyebutkan bahwa individual competence dibentuk melalui beberapa tahapan, yaitu dimulai dari mahasiswa memiliki persepsi negatif mengenai korupsi, persepsi positif mengenai antikorupsi, menguatnya kesadaran (awareness) terhadap adanya potensi tindak korupsi sehingga pada akhirnya mahasiswa memiliki sikap antikorupsi dalam arti berusaha untuk tidak melakukan tindak korupsi dalam bentuk apapun dan sekecil apapun. Dengan tercapainya standar kompetensi yang kedua, diharapkan mahasiswa mampu menularkan sikap antikorupsi kepada lingkungan sekitarnya yang dapat ditunjukkan melalui beberapa tindakan nyata misalnya berani mengingatkan orang lain agar tidak melakukan tindak korupsi serta memberikan informasi kepada orang lain mengenai halhal terkait korupsi dan antikorupsi. Dengan tercapainya standar kompetensi yang ketiga diharapkan mahasiswa mampu mendeteksi adanya suatu tindak korupsi secara komprehensif mulai bentuk, proses, peraturan yang dilanggar, pelaku, kerugian/dampak yang ditimbulkan di mana untuk selanjutnya, mampu dihasilkan penyelesaian masalah [13].

Berdasarkan hasil studi lapangan dan studi literatur, dapat dirumuskan kebutuhan pengguna untuk media pembelajaran yang akan dikembangkan adalah pertama, cakupan materi cukup fleksibel. Dalam hal ini media pembelajaran dapat digunakan di perguruan tinggi yang menyisipkan materi pendidikan antikorupsi di mata kuliah tertentu maupun yang menyajikannya dalam mata kuliah tersendiri. Kedua, materi disajikan melalui media yang menarik, variatif, dan kontekstual sesuai dengan situasi serta kondisi yang ditemui oleh mahasiswa

Berdasarkan kebutuhan pengguna, dikembangkan sebuah media pembelajaran yang terdiri dari empat materi yang dirancang untuk disajikan dalam enam kali pertemuan dengan pertimbangan bila materi pendidikan antikorupsi disampaikan dalam mata kuliah tersendiri penyajian setiap materi dapat diperdalam dan dikembangkan untuk disajikan dalam 14 kali pertemuan. Sebaliknya, bila materi pendidikan antikorupsi disampaikan dengan disisipkan dalam mata kuliah tertentu maka penyajian setiap materi dapat dipersingkat disesuaikan dengan waktu yang tersedia.

Silabus terdiri dari: (1) Definisi dan faktor penyebab terjadinya korupsi, yang disajikan dalam satu kali pertemuan; (2) Bentuk-bentuk perbuatan korupsi, kerugian keuangan negara, suap menyuap, dan penggelapan dalam jabatan, pemerasan, perbuatan curang, benturan kepentingan dalam pengadaan, dan gratifikasi yang disajikan dalam dua kali pertemuan; (3) Dampak masif dan upaya pemberantasan korupsi yang disajikan dalam satu kali pertemuan; dan (4) Nilai dan prinsip antikorupsi: kejujuran, kepedulian, kemandirian, dan kedisiplinan, tanggung jawab, kesederhanaan, kerja keras, dan keadilan yang dijsaikan dalam dua kali pertemuan.

Agar materi yang disajikan menarik, maka di masing-masing materi ditambahkan unsur multimedia. Pada materi pertama yaitu definisi dan faktor penyebab terjadinya korupsi ditambahkan film pendek berupa animasi, pada materi kedua yaitu bentuk-bentuk perbuatan korupsi ditambahkan beberapa video, pada materi ketiga yaitu dampak masif dan upaya pemberantasan korupsi ditambahkan games dan pada materi keempat yaitu nilai dan prinsip antikorupsi ditambahkan potongan rekaman sebuah acara televisi yang membahas tentang seorang okoh antikorupsi. Data selengkapnya tersaji di Tabel 1.

Tabel 1. Elemen multimedia di masing-masing materi

\begin{tabular}{|c|c|c|c|}
\hline Pert & Materi & $\begin{array}{c}\text { Elemen } \\
\text { Multimedia }\end{array}$ & Keterangan \\
\hline 1 & $\begin{array}{l}\text { Definisi } \\
\text { Korupsi }\end{array}$ & 2 film animasi & $\begin{array}{l}\text { Animasi 1: } \\
\text { Topik: Perilaku } \\
\text { suap dalam proses } \\
\text { pembuatan KTP } \\
\text { Durasi: } 1 \text { menit } 30 \text { detik } \\
\text { Animasi } 2 \text { : } \\
\text { Topik: Gaya hidup } \\
\text { mewah } \\
\text { Durasi: } 1 \text { menit } 11 \text { detik }\end{array}$ \\
\hline 2,3 & $\begin{array}{l}\text { Bentuk } \\
\text { Perbuatan } \\
\text { Korupsi }\end{array}$ & $\begin{array}{l}3 \text { video tentang } \\
\text { contoh perbuatan } \\
\text { korupsi yang } \\
\text { sering terjadi } \\
\text { di kalangan } \\
\text { mahasiswa }\end{array}$ & $\begin{array}{l}\text { Video 1: } \\
\text { Topik: Titip Absen } \\
\text { Durasi: } 48 \text { detik } \\
\text { Video 2: } \\
\text { Topik : Menyuap Pak } \\
\text { Polisi } \\
\text { Durasi: } 1 \text { menit } 27 \text { detik } \\
\text { Video 3: } \\
\text { Topik: Mencontek } \\
\text { Durasi: } 3 \text { menit } 30 \text { detik }\end{array}$ \\
\hline 4 & $\begin{array}{l}\text { Dampak } \\
\text { Masif } \\
\text { Perbuatan } \\
\text { Korupsi }\end{array}$ & $\begin{array}{l}\text { Permainan wheel } \\
\text { of fortune }\end{array}$ & \\
\hline 5,6 & $\begin{array}{l}\text { Nilai dan } \\
\text { Prinsip } \\
\text { Antikorupsi }\end{array}$ & $\begin{array}{l}\text { Potongan } \\
\text { rekaman acara } \\
\text { Kick. Andy dari } \\
\text { Youtube }\end{array}$ & $\begin{array}{l}\text { Topik: Jenderal } \\
\text { Hoegeng } \\
\text { Durasi: } 36 \text { menit }\end{array}$ \\
\hline
\end{tabular}

Pada tahap perancangan, sesuai dengan rumusan kebutuhan pengguna, dirancang sebuah media pembelajaran pendidikan antikorupsi berbasis multimedia yang disebut MedPAK. Perancangan MedPAK dilakukan dengan menggunakan UML sebagai alat bantu dan menggunakan aplikasi Visio 2010 untuk pemodelannya. Use case diagram MedPAK disajikan dalam Gambar 1. 


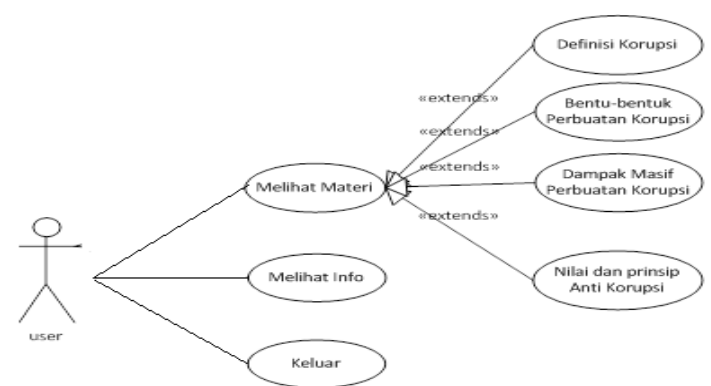

Gambar 2. Use case diagram MedPAK

MedPAK memiliki tiga fungsi yaitu untuk Melihat Materi, Melihat Info, dan Keluar. Pada fungsi Melihat Materi terdapat empat fungsi ekstensi untuk mengakses materi masing-masing pertemuan yaitu fungsi Definisi Korupsi (materi pertemuan I), Bentuk-bentuk Perbuatan Korupsi (pertemuan II dan III), Dampak Masif Perbuatan Korupsi (pertemuan IV) dan Nilai dan Prinsip Antikorupsi (pertemuan V dan VI). Masing-masing materi terdiri dari materi kuliah dan unsur multimedia yang berupa animasi, potongan video, potongan berita, atau film pendek yang diarahkan untuk dimanfaatkan sebagai bahan diskusi, kuis, maupun roleplay bagi mahasiswa. Fungsi Melihat Info digunakan untuk melihat informasi tentang media ini dan profil pengembang.

MedPAK dikembangkan dengan menggunakan beberapa perangkat lunak yaitu 3 dmaya v.9 2015, Adobe After Effect 2015, Adobe Premiere CC 2015, dan Adobe Media Encoder 2015. 3dmaya v.9 2015 digunakan untuk memodelkan karakter dan beberapa objek yang akan digunakan dalam alur cerita. Adobe After Effect 2015 digunakan dalam pembuatan alur cerita atau storyboard dengan menggunakan karakter dan objek-objek yang telah dibuat sebelumnya kemudian ditambahkan musik latar belakang. Setelah itu dilakukan proses render utk menghasilkan animasi. Adobe Premiere CC 2015 digunakan untuk memperhalus gerakan animasi hasil render. Adobe Media Encoder 2015 digunakan untuk mengubah jenis file video hasil render dalam hal ini file dengan ekstensi avi diubah menjadi ekstensi .mp4 agar bisa terbaca dan ditempelkan di beberapa software lain, juga berfungsi utk mengurangi kapasitas file dr hasil render.

Beberapa tampilan MedPAK disajikan pada gambargambar berikut. Halaman utama MedPAK disajikan pada Gambar 3 dan tampilan Menu Utama pada Gambar 4. Di Menu Utama terdapat 4 tombol yaitu Definisi Korupsi, Bentuk-bentuk Perbuatan Korupsi, Dampak Masif Perbuatan Korupsi dan Nilai \& Prinsip Antikorupsi untuk mengakses masing-masing materi. Bila tombol diklik akan muncul materi kuliah dan unsur multimedia yang sesuai dengan materi tersebut.

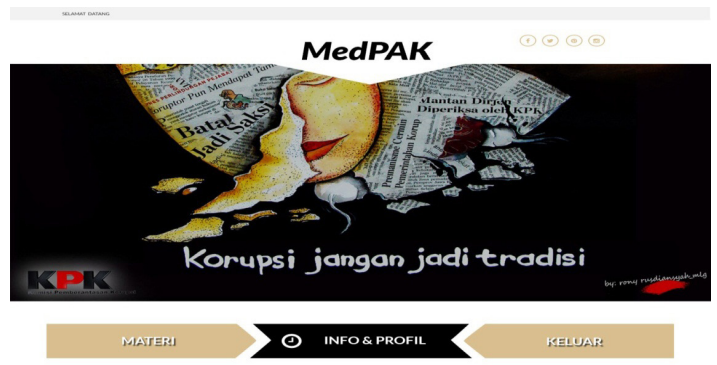

Gambar 3. Halaman utama MedPAK

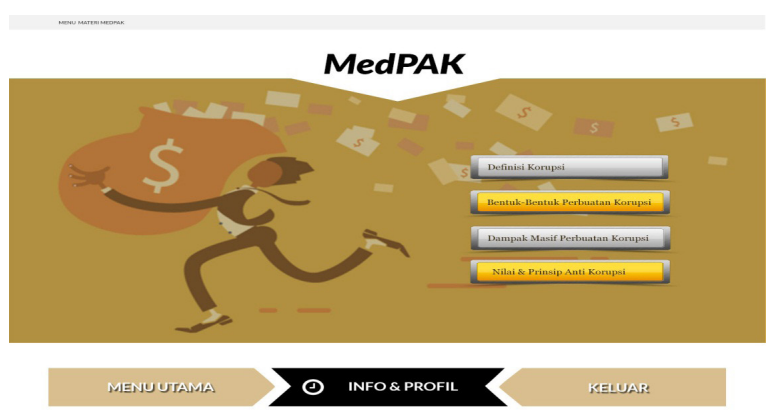

Gambar 4 Menu utama MedPAK

Untuk memastikan bahwa model pembelajaran yang dirancang telah sesuai dengan kebutuhan maka dilakukan penilaian materi dan penilaian media. Penilaian materi dilakukan oleh ahli materi yang terdiri dari tiga orang dosen pengampu mata kuliah Pendidikan Kewarganegaraan sekaligus penggiat komunitas anti korupsi yang bereputasi di Jawa Tengah. Ahli materi diminta memberikan penilaian terhadap beberapa aspek yaitu: kejelasan indikator, kesesuaian materi dengan indikator, kejelasan isi materi, kelengkapan materi, ketepatan urutan materi, kedalaman materi, kejelasan penyampaian materi, kesesuaian soal dengan materi, kecukupan latihan, kesesuaian dengan kondisi mahasiswa, kesesuaian materi dengan mahasiswa, dan kesesuaian kalimat dengan mahasiswa [14]. Setiap aspek diukur dengan indikator tertentu di mana untuk masing-masing indikator jangkauan skor adalah mulai dari Sangat tidak baik (skor 1), Tidak baik (skor 2), Netral (skor 3), Baik (4), dan Sangat baik (Skor 5). Skor yang diperoleh kemudian dikonversikan ke dalam bentuk persentase. Hasil penilaian disajikan pada Tabel 2 .

Tabel 2. Hasil penilaian ahli materi

\begin{tabular}{clcc}
\hline No & \multicolumn{1}{c}{ Aspek } & Skor & $\%$ \\
\hline 1 & Kejelasan capaian pembelajaran & 4,7 & $94 \%$ \\
2 & Kejelasan indikator & 4,3 & $86 \%$ \\
3 & Kesesuaian materi dengan indikator & 4,3 & $86 \%$ \\
4 & Kejelasan isi materi & 4,4 & $88 \%$ \\
5 & Kelengkapan materi & 4,2 & $84 \%$ \\
6 & Ketepatan urutan materi & 4,3 & $86 \%$ \\
7 & Kedalaman materi & 4,1 & $82 \%$ \\
8 & Kejelasan penyampaian materi & 4,3 & $86 \%$ \\
9 & Kecukupan latihan & 4,0 & $80 \%$ \\
10 & Kesesuaian materi dengan kondisi mahasiswa & 4,5 & $90 \%$ \\
11 & Kesesuaian materi dengan mahasiswa & 4,8 & $96 \%$ \\
12 & Kesesuaian kalimat dengan mahasiswa & 4,3 & $86 \%$ \\
\hline \multirow{2}{*}{ Rata-rata Total } & 4,4 & $\mathbf{8 8 \%}$ \\
\hline
\end{tabular}

Data yang tersaji di Tabel 2 menunjukkan bahwa untuk setiap aspek yang diamati persentase yang dicapai lebih besar atau sama dengan $80 \%$. Persentase terendah adalah pada aspek kecukupan latihan yaitu sebesar 80\% sedangkan tertinggi adalah pada aspek kesesuaian materi dengan mahasiswa yaitu sebesar 96\%. Secara keseluruhan rata-rata persentase hasil penilaian dari ahli materi adalah $88 \%$ dan termasuk kategori baik. Hal ini menunjukkan bahwa dilihat dari aspek materi, MedPAK layak untuk digunakan. 
Penilaian media dilakukan oleh beberapa ahli media pembelajaran yang memiliki kompetensi dan pengalaman yang memadai dalam hal pengembangan media pembelajaran. Ahli media diminta untuk memberikan skor terhadap aspek muatan emosi dalam pembelajaran, keselarasan ilustrasi visual dan deskripsi, akurasi, cakupan serta kesederhanaan pengoperasian. Hasil penilaian ahli media disajikan dalam Tabel 3. Jangkauan skor yang digunakan sama dengan yang digunakan dalam penilaian materi yaitu mulai dari 1 (sangat tidak baik) sampai dengan 5 (sangat baik) untuk kemudian dikonversikan menjadi bentuk persentase.

Tabel 3. Hasil penilaian ahli media

\begin{tabular}{|c|c|c|c|}
\hline \multicolumn{4}{|c|}{ Muatan emosi dalam pembelajaran } \\
\hline No & Indikator & $\begin{array}{l}\text { Skor } \\
(\%)\end{array}$ & $\begin{array}{c}\text { Total } \\
\text { Aspek }\end{array}$ \\
\hline 1 & $\begin{array}{l}\text { Perasaan bahwa melaksanakan } \\
\text { pembelajaran menggunakan MedPAK } \\
\text { adalah perbuatan baik }\end{array}$ & $\begin{array}{c}4,5 \\
(90 \%)\end{array}$ & $\begin{array}{c}4,3 \\
(86 \%)\end{array}$ \\
\hline 2 & $\begin{array}{l}\text { Keyakinan bahwa pembelajaran } \\
\text { pendidikan antikorupsi dapat digunakan } \\
\text { untuk tujuan yang baik }\end{array}$ & $\begin{array}{c}4,2 \\
(84 \%)\end{array}$ & \\
\hline 3 & $\begin{array}{l}\text { Perasaan bahwa pendidikan antikorupsi } \\
\text { sangat penting }\end{array}$ & $\begin{array}{c}4,2 \\
(84 \%)\end{array}$ & \\
\hline 4 & $\begin{array}{l}\text { Perasaaan bahwa MedPAK menempatkan } \\
\text { pendidikan antikorupsi sebagai } \\
\text { pengetahuan yang berharga }\end{array}$ & $\begin{array}{c}4,3 \\
(86 \%)\end{array}$ & \\
\hline \multicolumn{4}{|c|}{ Keselarasan ilustrasi visual dan deskripsi } \\
\hline 5 & $\begin{array}{l}\text { Mahasiswa mendapat informasi melalui } \\
\text { gambar,animasi atau media lainnya beserta } \\
\text { keterangannya }\end{array}$ & $\begin{array}{c}4,2 \\
(84 \%)\end{array}$ & $\begin{array}{c}4,1 \\
(82 \%)\end{array}$ \\
\hline 6 & $\begin{array}{l}\text { Mahasiswa lebih memahami informasi } \\
\text { dengan adanya gambar, animasi atau media } \\
\text { lainnya }\end{array}$ & $\begin{array}{c}4,1 \\
(82 \%)\end{array}$ & \\
\hline 7 & $\begin{array}{l}\text { Mahasiswa dapat memahami maksud } \\
\text { setiap gambar, animasi, atau media lainnya }\end{array}$ & $\begin{array}{c}4,1 \\
(82 \%)\end{array}$ & \\
\hline \multicolumn{4}{|c|}{ Akurasi } \\
\hline 8 & Tidak ditemukan informasi yang salah & $\begin{array}{c}4,3 \\
(86 \%)\end{array}$ & 4,2 \\
\hline 9 & $\begin{array}{l}\text { Pengguna mendapat informasi yang baru } \\
\text { atau dengan cara pandang yang baru }\end{array}$ & $\begin{array}{c}4,2 \\
(84 \%)\end{array}$ & \\
\hline 10 & $\begin{array}{l}\text { Pengguna memahami kalimat-kalimat yang } \\
\text { digunakan dalam MedPAK }\end{array}$ & $\begin{array}{c}4,0 \\
(80 \%)\end{array}$ & \\
\hline 11 & $\begin{array}{l}\text { Informasi yang disajikan dalam MedPAK } \\
\text { objektif }\end{array}$ & $\begin{array}{c}4,1 \\
(82 \%)\end{array}$ & \\
\hline 12 & $\begin{array}{l}\text { Gambar, animasi, atau media lainnya } \\
\text { digunakan dengan tepat }\end{array}$ & $\begin{array}{c}4,1 \\
(82 \%)\end{array}$ & \\
\hline 13 & $\begin{array}{l}\text { Tidak ditemukan gambar, animasi, atau } \\
\text { media lainnya yang berlebihan }\end{array}$ & $\begin{array}{c}4,2 \\
(84 \%)\end{array}$ & \\
\hline \multicolumn{4}{|c|}{ Cakupan } \\
\hline 14 & $\begin{array}{l}\text { Mahasiswa dapat memahami alur cerita } \\
\text { dalam MedPAK }\end{array}$ & $\begin{array}{c}4,1 \\
(82 \%)\end{array}$ & $\begin{array}{c}4,1 \\
(82 \%)\end{array}$ \\
\hline 15 & $\begin{array}{l}\text { Contoh kasus yang disajikan sesuai dengan } \\
\text { konteks dunia mahasiswa }\end{array}$ & $\begin{array}{c}4,2 \\
(84 \%)\end{array}$ & \\
\hline 16 & $\begin{array}{l}\text { Games dalam MedPAK dapat membantu } \\
\text { mahasiswa lebih memahami materi yang } \\
\text { disajikan }\end{array}$ & $\begin{array}{c}4,0 \\
(80 \%)\end{array}$ & \\
\hline \multicolumn{4}{|c|}{ Kesederhanaan pengoperasian } \\
\hline 17 & MedPAK mudah diinstal & $\begin{array}{c}4,2 \\
(84 \%)\end{array}$ & $\begin{array}{c}4,3 \\
(86 \%)\end{array}$ \\
\hline 18 & MedPAK mudah digunakan & $\begin{array}{c}4,4 \\
(88 \%)\end{array}$ & \\
\hline 19 & $\begin{array}{l}\text { MedPAK berjalan dengan baik di } \\
\text { komputer }\end{array}$ & $\begin{array}{c}4,4 \\
(88 \%)\end{array}$ & \\
\hline \multirow[t]{2}{*}{20} & $\begin{array}{l}\text { Di monitor, seluruh bagian program dapat } \\
\text { terlihat dengan baik }\end{array}$ & $\begin{array}{c}4,3 \\
(86 \%)\end{array}$ & \\
\hline & Total & & $\begin{array}{c}4,2 \\
(84 \%)\end{array}$ \\
\hline
\end{tabular}

Dari Tabel 3 terlihat bahwa persentase masingmasing indikator dan masing-masing aspek paling rendah adalah $80 \%$ dan termasuk dalam kategori baik. Dari 20 indikator yang diukur, persentase tertinggi adalah 90\% terdapat pada indikator perasaan babwa melaksanakan pembelajaran menggunakan MedPAK adalah perbuatan baik sedangkan persentase terendah adalah $80 \%$ terdapat pada indikator pengguna memahami kalimat-kalimat yang digunakan dalam MedPAK dan games dalam MedPAK dapat membantu mahasiswa lebih memahami materi yang disajikan. Hal ini menunjukkan bahwa para ahli media memberikan respons yang positif terhadap MedPAK walaupun dalam beberapa hal MedPAK perlu disempurnakan terutama dalam hal penulisan kalimat dan penyisipan games yang lebih sesuai dengan materi yang dibahas.

Dari masing-masing aspek yang diamati dan diukur, persentase untuk aspek muatan emosi dalam pembelajaran mencapai $86 \%$, persentase keselarasan ilustrasi visual dan deskripsi mencapai $82 \%$, aspek akurasi $84 \%$, cakupan $82 \%$, dan aspek kesederhanaan pengoperasian mencapai skor $86 \%$. Secara keseluruhan, rata-rata persentase adalah $84 \%$ dan termasuk kategori baik. Hal ini menunjukkan bahwa dilihat dari aspek media, MedPAK layak untuk digunakan.

\section{Kesimpulan}

MedPAK dikembangkan agar dapat digunakan secara fleksibel baik untuk pendidikan antikorupsi yang disajikan dalam mata kuliah tersendiri maupun disisipkan dalam mata kuliah lain. Bahan ajar yang tersaji dalam MedPAK terdiri dari 4 materi yaitu definisi korupsi, bentuk perbuatan korupsi, dampak masif perbuatan korupsi serta nilai dan prinsip antikorupsi. Agar menarik, di setiap materi disisipkan unsur multimedia dan ditambahkan contoh kasus-kasus yang sesuai dengan dunia mahasiswa. MedPAK dikembangkan dengan mengadopsi metode penelitian dan pengembangan (Research and DevelopmentR\&D). Dengan metode ini, hasil penilaian materi pada MedPAK menunjukkan rata-rata persentase adalah $88 \%$ sedangkan hasil penilaian media menunjukkan rata-rata skor adalah $84 \%$ yang dalam hal ini keduanya termasuk kategori baik. Hasil ini sesuai dengan penelitian Hernawati di mana dengan metode yang sama, pada media yang dikembangkan hasil penilaian materi menunjukkan ratarata persentase sebesar $94,2 \%$ dan hasil penilaian media menunjukkan rata-rata persentase sebesar 80,4\% yang dalam hal ini keduanya termasuk dalam kategori sangat baik [15]. Hasil yang serupa juga ditunjukkan oleh Kuswanto, yang menyebutkan bahwa pada media yang dikembangkan dengan metode yang sama hasil penilaian materi adalah sebesar $84 \%$ sedangkan hasil penilaian media mencapai 84,9\% dan termasuk kategori baik [16].

\section{Persantunan}

Terima kasih atas dukungan Kementerian Riset, Teknologi dan Pendidikan Tinggi Direktorat Jenderal Penguatan Riset dan Pengembangan Direktorat Penelitian dan Pengabdian Masyarakat dengan nomor kontrak 031/ K6/KM/SP2H/PENELITIAN/2018 


\section{Daftar Pustaka}

[1] F. Hidayat, "Fakta: Indeks Korupsi Indonesia Terus Membaik," Kompasiana, 2014. [Online]. Available: https://www.kompasiana.com. [Accessed: 10-Nov-2018].

[2] Komisi Pemberantasan Korupsi, "Statistik Tindak pidana korupsi," Komisi Pemeberantasan Korupsi, 2018. [Online]. Available: htttps://aceh.kpk.go.id.

[3] Kementrian Keuangan Republik Indonesia, "Jaringan Data dan Informasi Hukum," Kementrian Keuangan Republike Indonesia, 2018. [Online]. Available: https://jdib.kemenkeu.go.id.

[4] Y. Kadir, "Kebijakan Pendidikan Anti Korupsi Di Perguruan Tinggi," Gorontalo Law Rev., vol. 1, no. 1, 2018.

[5] F. Hasan, Pendidikan Adalah Pembudayaan: Dalam Pendidikan Manusia Indonesia. Jakarta: Penerbit Kompas, 2004.

[6] I. Suryani, "Penamaan Nilai-Nilai Anti Korupsi Di Lembaga Pendidikan Perguruan Tinggi Sebagai Upaya Preventif pencegahan Korupsi,"J. Visi Komun., vol. 14, no. 02, 2015.

[7] L. Bimantoro, "Visualisasi Rasi Bintang Berbasis Multimedia,” Universitas Negeri Syarif Hidayatullah, 2011.

[8] Y. Pariyatin, "Perancangan Media PembelajarannInteraktif Pendidikan Pancasila Berbasis Multimedia (Studi Kasus Mahasiswa Semester I STT-Garut)," J. Algoritm., vol. 12, no. No. 1, 2015.

[9] G. P. A. Oka, Media dan Multimedia Pembelajaran. Dee Publish, 2017.
[10] A. Efendi, Anwar, S. Sumarni, A. Efendi, "Pengembangan Media Pembelajaran Berbasis Video Tutorial Pada Mata Kuliah mekanika Tanah," J. Pendidik. Tek. Bangunan, vol. 1, no. 1, 2015.

[11] M. Rasyid, A.A. Azis, A.R. Saleh, "Pengembangan Media Pembelajaran Berbasis Multimedia Dalam Konsep Sistem Indera Pada Siswa Kelas XI SMA," J. Pendidik. Biol., vol. 7, no. 2, 2016.

[12] Tim Penulis Buku Pendidikan Anti Korupsi, Pendidikan Anti Korupsi Untuk Perguruan Tinggi. Jakarta: Kementerian Pendidikan dan Kebudayaan RI Direktorat Jenderal Pendidikan Tinggi Bagian Hukum Kepegawaian, 2011.

[13] N.S. Junaedi, I. Susanti, Sumiyati, "Model Pembelajaran Pendidikan Antikorupsi Di Lingkungan Politeknik Negeri Bandung," SigmaMu, vol. 6, no. 1, 2014.

[14] M. Sariyono, K. Endro, "Pengembangan Multimedia Pembelajaran Kartografi Pada Jurusan Pendidikan Geografi Fakultas Ilmu Sosial UNY," J. Inov. Teknol. Pendidik., vol. 3, no. 2, pp. 207-220, 2016.

[15] E.R.. Hernawati, C. Ruhidawati, "Pengembangan Multimedia Video Pembelajaran Pengoperasian Mesin Jahit Industri," Fesyen Perspekt., vol. 7, no. 2, 2016.

[16] J. Kuswanto, Y. Walusfa, "Pengembangan Multimedia Pembelajaran pada Mata Pelajaran Teknologi Informasi dan Komunikasi Kelas VIII," Innov. J. Curric. Educ. Technol. IJCET, vol. 6, no. 2, pp. 58-64, 2017. 